\title{
The Measurement of Amniotic Fluid $\alpha_{2}$ Macroglobulin by Fixed Time Kinetic Immunoturbidimetry
}

\author{
By K. Spencer ${ }^{1}$ ) \\ Department of Chemical Pathology, General Hospital, Southampton, U.K.,
}

\section{E. J. Coombes}

Department of Chemical Pathology, General Infirmary, Salisbury, U.K. and

\section{P. J. Wood}

Department of Chemical Pathology, General Hospital, Southampton, U.K.

(Received May 28/September 6, 1982)

Summary: We have developed an assay for $\alpha_{2}$ macroglobulin in amniotic fluid, based on the technique of Fixed Time Kinetic Immunoturbidimetry. The assay is precise (CV 5\% between assays) and has a detection limit of $0.4 \mathrm{mg} / \mathrm{l}$. We have determined the reference range for $\alpha_{2}$ macroglobulin from 100 amniotic fluid samples from none Neural Tube Defect pregnancies. The data indicates no significant variation of $\alpha_{2}$ macroglobulin with gestational age and that the results in none Neural Tube Defect pregnancies showed a narrow reference range with a mean of $1.67 \mathrm{mg} / \mathrm{l}$ and $\mp 2 \mathrm{SD}$ range of $0.23-3.11 \mathrm{mg} / \mathrm{l}(99$ percentile $=3.65 \mathrm{mg} / \mathrm{l})$. Results in 25 Neural Tube Defect pregnancies are presented.

\section{Bestimmung von $\alpha_{2}$-Makroglobulin im Fruchtwasser durch „fixed time"-kinetische Immunturbidimetrie}

Zusammenfassung: Die Bestimmung von $\alpha_{2}$-Makroglobulin im Fruchtwasser durch "fixed time"-kinetische Immunturbidimetrie wird beschrieben. Das Verfahren zeigt zwischen den Serien einen Variationskoeffizienten von $5 \%$ und hat eine Nachweisgrenze von $0,4 \mathrm{mg} / \mathrm{l}$. Der Referenzbereich für $\alpha_{2}$-Makroglobulin wurde an 100 Fruchtwasserproben von Schwangerschaften ermittelt, bei denen kein Neuralrohrdefekt bestand. Signifikante Änderungen der $\alpha_{2}$-Makroglobulinkonzentration mit der Schwangerschaftsdauer wurden nicht beobachtet, die untersuchten Proben ergaben einen schmalen Referenzbereich mit $\overline{\mathbf{x}}=1,67 \mathrm{mg} / \mathrm{l}$ und $\overline{\mathrm{x}}$ $\pm 2 \mathrm{~s}=0,23=3,11 \mathrm{mg} / \mathrm{l}$ (99. Perzentil 3,65 $\mathrm{mg} / \mathrm{l})$. Die Ergebnisse von Untersuchungen an 25 Schwangerschaften mit Neuralrohrdefekt werden mitgeteilt.

\section{Introduction}

Amniotic fluid $\alpha$-fetoprotein measurements are widely used as a follow up to maternal serum $\alpha$-fetoprotein screening for the detection of neural tube defects. However amniotic fluid $\alpha$-fetoprotein estimations have their limitations. Levels decrease with

1) Present address; Department of Biochemistry, Oldchurch Hospital, Romford, Essex, U.K. gestational age, and if a cut off level of $5 \mathrm{SD}$ above the mean for normal pregnancies is taken, $10 \%$ of open spina bifida cases may be missed (1). Raised amniotic fluid $\alpha$-fetoprotein levels are associated with threatened abortion, fetal death, exomphalos, congenital nephrosis, Turner's syndrome and several other disorders. There is a need for additional information to improve the success rate for detection of neural tube defects and to identify cases with high results due to other causes. 
The use of concanavalin A affinity chromatographic fractionation of $\alpha$-fetoprotein (2), gel electrophoretic fractionation of cholinesterase activity (3) and $\alpha_{2}$ macroglobulin estimations (4) have been proposed as possible adjuncts to total amniotic fluid $\alpha$-fetoprotein measurements in the identification of neural tube defects. The relative merits of the three additional tests in the evaluation of false positive, borderline and false negative total amniotic fluid $\alpha$-fetoprotein results have been recently outlined $(5,6)$.

Measurements of $\alpha_{2}$ macroglobulin in amniotic fluid have either involved "rocket" immunoelectrophoresis $(4,7)$ or continuous flow nephelometry $(8)$. Rocket electrophoresis whilst being sensitive (detection limit $0.1 \mathrm{mg} / \mathrm{l}$ ) is time consuming and imprecise compared with the newer techniques such as Kinetic Immunoturbidimetry (9) which are rapid, automatable and almost as sensitive.

This paper describes the development of an assay for amniotic fluid $\alpha_{2}$ macroglobulin by a Fixed Time Kinetic Immunoturbidimetric technique and the determination of reference values.

\section{Materials and Methods}

Instrumentation

In this study we used the LKB 2086 Mark II Kinetic Analyser with Kinetic Data Processor and recorder (Clinicon Systems Ltd., Bromma, Sweden).

\section{Reagents}

All reagents were obtained from British Drug Houses, Poole, Dorset, U.K., except where stated.

Phosphate buffer $(0.05 \mathrm{~mol} / 1$ phosphate, $0.1 \mathrm{~mol} / \mathrm{l}$ sodium chloride, $22.5 \mathrm{mmol} / \mathrm{I}$ EDTA, pH $7.40 \mp 0.02$ ): Dissolve $5.85 \mathrm{~g}$ of sodium chloride, $9.10 \mathrm{~g}$ of di potassium ethylene diaminetetra acetate dihydrate, $7.16 \mathrm{~g}$ of di sodium hydrogen phosphate and $1.33 \mathrm{~g}$ of potassium di hydrogen phosphate in $950 \mathrm{ml}$ distilled water and dilute to 1 litre. The buffer is stable at $4^{\circ} \mathrm{C}$ for at least one month.

Phosphate buffer with polyethylene glycol 6000 : Dissolve $40 \mathrm{~g}$ of polyethylene glycol 6000 (PEG) in $800 \mathrm{ml}$ of the above buffer and dilute to 1 litre with buffer. This solution is stable at $4^{\circ} \mathrm{C}$ for at least one month.

Stock anti human $\alpha_{2}$ macroglobulin antisera: Sheep anti human $\alpha_{2}$ macroglobulin (Seward Laboratory, UAC House, Blackfriars Road, London; Product no. BA 14). Prepare working antiserum dilutions by making the appropriate dilution with buffer/PEG reagent, allowing it to stand for 30 minutes at room temperature and centrifuging ( $1950 \mathrm{~g}, 10$ minutes) to remove any precipitate.

Standards: Standards were prepared from Hoechst Protein Standard Serum LC-V (Hoechst Pharmaceuticals, Hounslow, U.K., Product no. OTFO 02/03), by dilution in $0.1 \mathrm{~mol} / \mathrm{l}$ saline to give a range of standards $1 \mathrm{mg} / \mathrm{l}-30 \mathrm{mg} / \mathrm{l}$.

Assay Procedures

Table 1 summarizes the assay arrangements, including instrument settings for the Fixed Time Kinetic Immunoturbidimetric protocol. The centrifuged sample is preincubated with buffer/PEG dil- uent at $37^{\circ} \mathrm{C}$ for as long as 15 minutes before the addition of diluted antiserum. The change in absorbance in the disposable $7 \mathrm{~mm}$ path length cuvets is monitored for 120 seconds on the 0.05 absorbance range. The absorbance change (corrected to a $10 \mathrm{~mm}$ path length) for the standards is used to construct a calibration curve by parabolic fit using the Data Processor, prior to automatic calculation of $\alpha_{2}$ macroglobulin concentration in the unknown samples. The operating programme, including callibrator values was stored on a tape cassette and could be recalled by use of an analysis code.

The first five tubes in a batch were standards, followed by unknown samples. The data processor presented the standard curve as absorbance changes (corrected to a $10 \mathrm{~mm}$ path length) and as a slope equation with a correlation coefficient followed by the respective calculated results for each unknown sample. Altêrñatively results can be calculated by graphical means, with use of the absorbance change during 120 seconds.

Before priming the reagent pump and tubing in the kinetic analyser, we filled the tubing with working antiserum solution and allowed it to equilibrate for 10 minutes, the solution was then returned to the reagent bottle and the tubing re-primed.

For comparison purposes the method used was a modification of the electroimmunoassay method of Laurell (10), using the Seward antiserum.

Tab. 1. Assay settings for amniotic fluid $\alpha_{2}$ macroglobulin assay.

Antiserum

Seward sheep anti human $\alpha_{2}$ macroglobulin diluted four fold with polyethylene glycol 6000 (PEG)/phosphate buffer.

Kinetic Analyser variables

Buffer/PEG

$300 \mu \mathrm{l}$

Sample or standard

$150 \mu \mathrm{l}$

Antiserum starter

$100 \mu \mathrm{l}$

Temperature

Wavelength

Light setting

Injection position

Measuring range

Delay function

Measuring interval

$37^{\circ} \mathrm{C}$

$340 \mathrm{~nm}$

Operate

Zero

0.05

On

120 seconds

\section{Results}

Several factors affect the antigen/antibody reaction and these have been described in detail elsewhere $(9$, $11,12,13)$. Reaction conditions investigated include $\mathrm{pH}$, temperature, sodium chloride concentrătion and polymer (polyethylene glycol 6000 ) concentration. Each parameter was shown to have similar optima to those indicated for other assays $(9,11-13)$.

The calibration curves for four separate assays are summarised in figure 1 . The recorder output from a typical calibration curve is shown in figure 2 , alongside three samples - sample $A$ from a normal pregnancy, sample $B$ from an neural tube defect pregnancy with an $\alpha_{2}$ macroglobulin level within the range of the assay, sample $\mathrm{C}$ from a neural tube defect pregnancy with an $\alpha_{2}$ macroglobulin level out- 


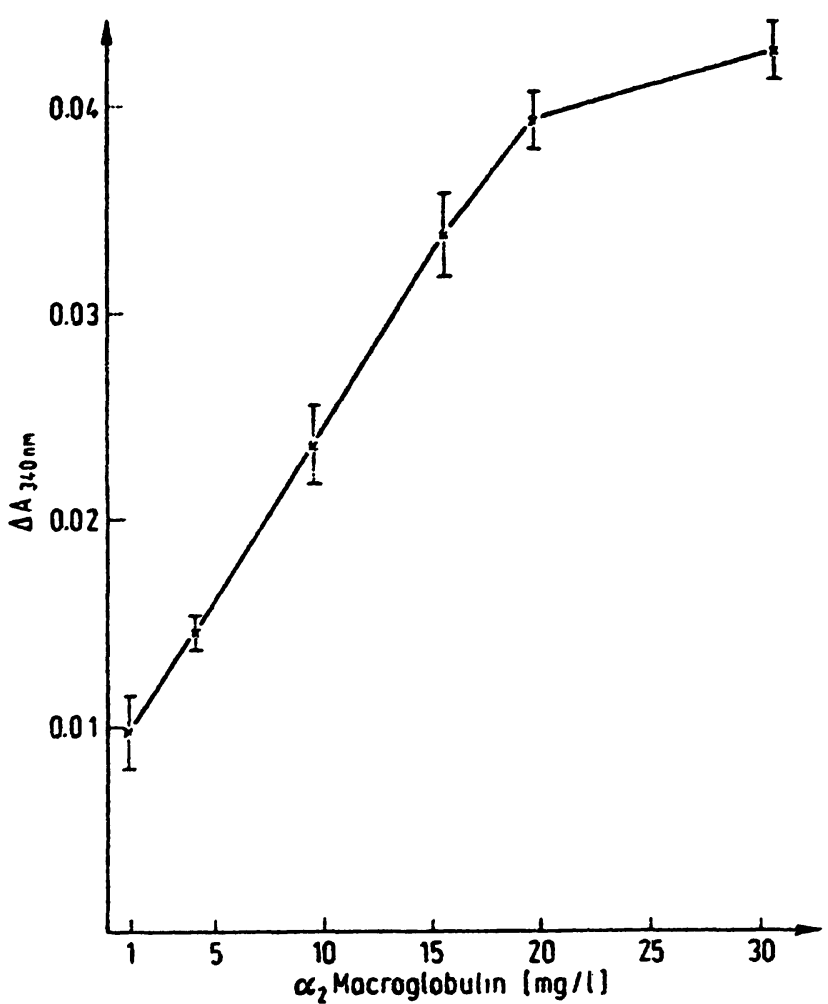

Fig. 1. $\alpha_{2}$ macroglobulin calibration curve for four separate runs. Each point shows $\dot{x} \pm s$.

side the range of the assay. Curve $C$ is a characteristic curve for a sample which has produced an antigen excess situation and as such is instantly recognisable and would be repeated with subsequent dilution of the sample.

\section{Detection limit}

The minimum detectable concentration of $\alpha_{2}$ macroglobulin in the assay system was determined by diluting a high neural tube defect specimen with a solution of human serum albumin $(10 \mathrm{~g} / \mathrm{l})$. The detection limit corresponded to an $\alpha_{2}$ macroglobulin concentration of $0.4 \mathrm{mg} / 1$ giving an absorbance change of 0.005 A per 120 seconds.

\section{Method performance}

\section{Precision}

Within run precision of the assay system was assessed by measuring replicates $(n=20)$ of three samples with different $\alpha_{2}$ macroglobulin levels; at $1.1 \mathrm{mg} / \mathrm{l}$ the $\mathrm{CV}$ was $5.8 \%$, at $3.1 \mathrm{mg} / \mathrm{l}$ the $\mathrm{CV}$ was $4.7 \%$ and at $23.8 \mathrm{mg} / 1$ the $\mathrm{CV}$ was $1.9 \%$.

Between run precision was assessed by analysing separate frozen aliquots $(n=10)$ of the samples. On each occasion a fresh dilution of antiserum was prepared. At a concentration of $3.4 \mathrm{mg} / \mathrm{l}$ the $\mathrm{CV}$ was $5.2 \%$ and $2.8 \%$ at $24.6 \mathrm{mg} / 1$.

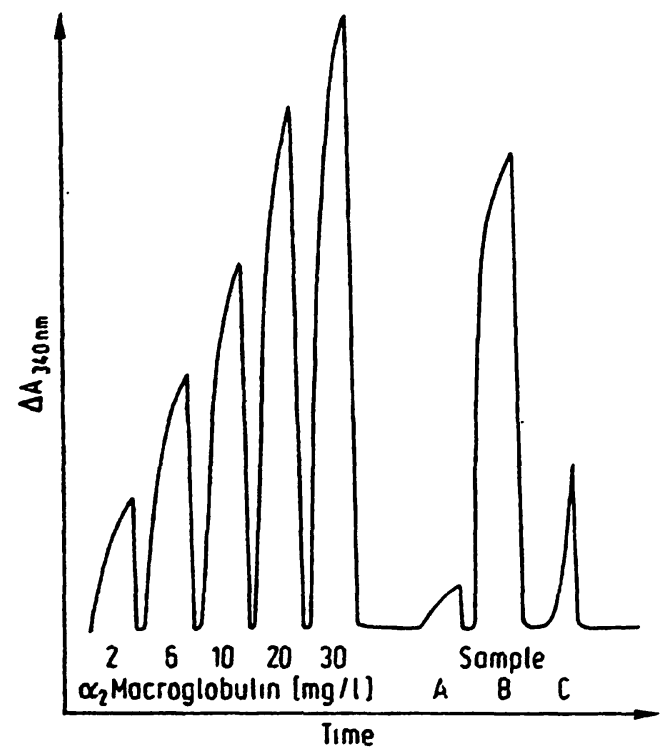

Fig. 2. Chart recording depicting a normal calibration curve followed by three samples.

$A=$ Normal pregnancy

$B=$ Neural Tube Defect pregnancy with $\alpha_{2}$ macroglobulin within the assay range

$\mathrm{C}=$ Neural Tube Defect pregnancy with $\alpha_{2}$ macroglobulin outside the assay range.

\section{Accuracy}

The IFCC Expert Panel on Nomenclature and Principles of Quality Control in Clinical Chemistry (14) recommends that method accuracy be assessed by using recovery checks with pure analyte and also by comparing the values obtained with samples assayed by a method of known accuracy. Because there is no internationally agreed upon standard or pure $\alpha_{2}$ macroglobulin available, accuracy could only be assessed by the latter method.

We compared patient samples analysed by the proposed method with the electroimmunoassay procedure. The regression parameters according to the Deming procedure were; $y=0.89 x+0.05(r=$ $0.918, \mathrm{n}=40$ ).

\section{Reference range}

Amniotic fluid specimens over a wide range of gestational age were kindly supplied by the Regional Centre, Department of Cytogenetics, Salisbury General Infirmary and were stored at $-20^{\circ} \mathrm{C}$ prior to analysis. Detailed study of the patients notes were taken after the birth to exclude any potentially abnormal samples. The samples were analysed for $\alpha_{2}$ macroglobulin concentration spread over six separate assays. 
Tab. 2. Variation of normal amniotic fluid $\alpha_{2}$ macroglobulin levels with gestational age.

\begin{tabular}{llllllll}
\hline Age (wecks) & 15 & 16 & 17 & 18 & 19 & 20 & $21-38$ \\
\hline $\bar{x}(\mathrm{mg} / \mathrm{l})$ & 1.58 & 1.70 & 1.89 & 1.92 & 1.46 & 1.75 & 1.49 \\
Range (mg/l) & $1.0-3.0$ & $0.7-3.8$ & $0.5-3.3$ & $1.0-3.4$ & $1.0-2.6$ & $1.0-2.8$ & $1.0-2.5$ \\
$\mathrm{~N}$ & 10 & 12 & 22 & 11 & 16 & 11 & 1. \\
\hline
\end{tabular}

The mean results for each week of pregnancy are shown in table 2 and the individual results plotted on a log scale in figure 3 . These results indicate a very narrow normal range, with an overall mean level of $1.67 \mathrm{mg} / \mathrm{l}$, $22 \mathrm{SD}$ range of $0.23-3.11 \mathrm{mg} / \mathrm{l}$ and a 99 th centile of $3.65 \mathrm{mg} / \mathrm{l}$. Furthermore the levels are independent of gestational age. These findings agree very closely with those of Haddow et al. (8) who also showed a mean of $1.7 \mathrm{mg} / \mathrm{l}$ and Van Kamp et al. (7) who also showed that levels were independent of gestational age.

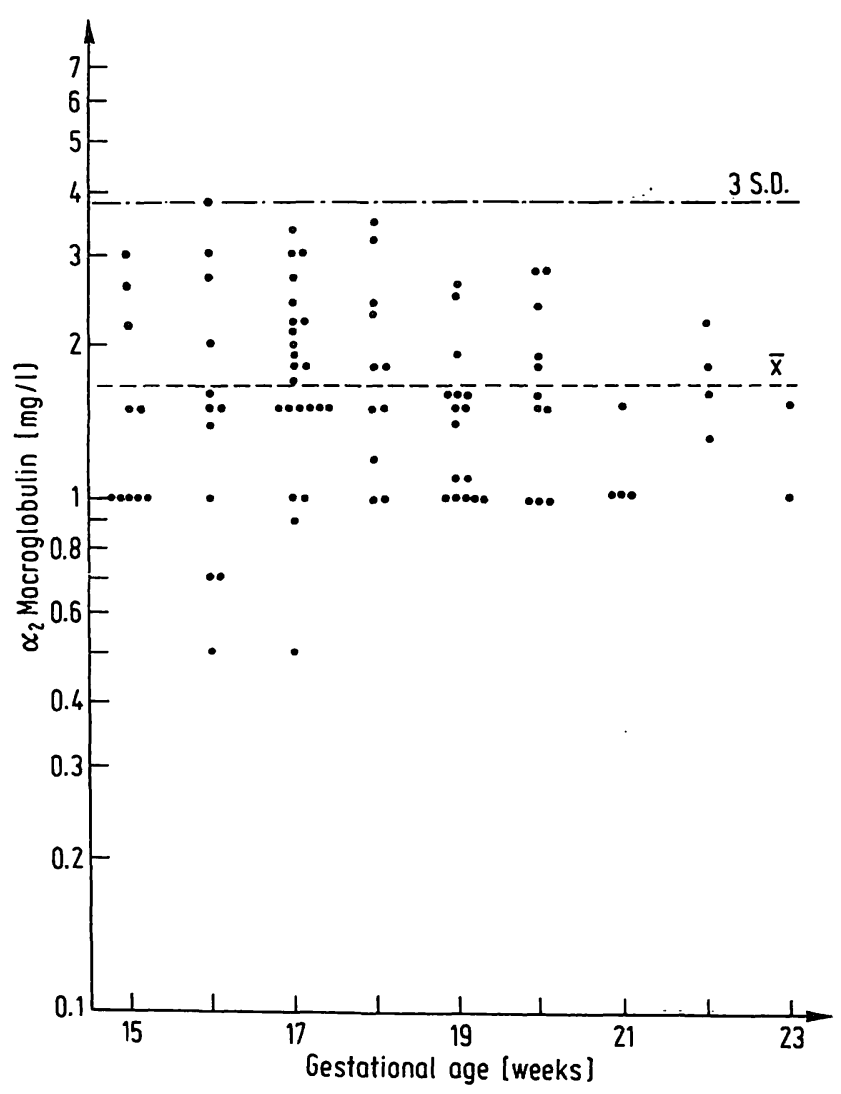

Fig. 3. Variation of normal amniotic fluid $\alpha_{2}$ macroglobulin levels with gestational age plotted on a log scale.

\section{Clinical application}

Amniotic fluid specimens from 25 known neural tube defect pregnancies were submitted for $\alpha_{2}$ macroglobulin analysis. The results relative to the refer- ence range are plotted on a log scale in figure 4 . The data clearly showes the separation of normal pregnanciēs from abnormal neural tube defect pregnancies.

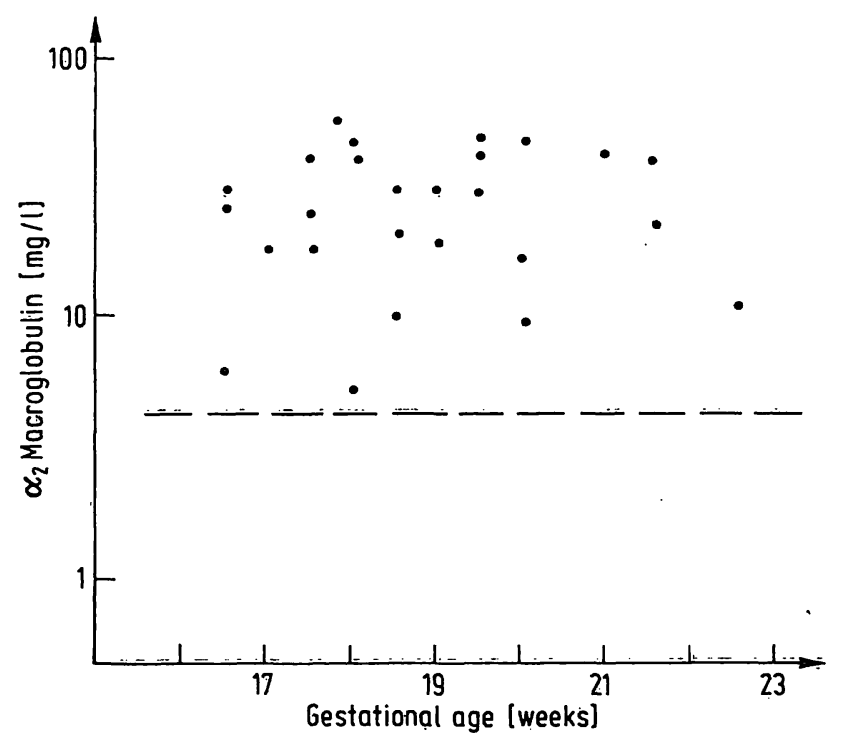

Fig. 4. $\alpha_{2}$ macroglobulin levels in 25 known Neural Tube Defect affected pregnancies.

\section{Conclusions}

A quick reliable assay for $\alpha_{2}$ macroglobulin has been developed and assessed using the technique of Fixed Time Kinetic Immunoturbidimetry. The reference range from 97 normal pregnancies. has been shown to be $0.23-3.11 \mathrm{mg} / \mathrm{l}$ (mean $-2 \mathrm{SD}$, 99th centile $3.65 \mathrm{mg} / \mathrm{l})$. The test has proven useful in providing additional information concerning the likely outcome of pregnancies presenting with equivocal amniotic fluid $\alpha$-fetoprotein levels. The data concerning this clinical study has been presented elsewhere $(5$, 6 ). The main drawback to the use of $\alpha_{2}$ macroglobulin assays in this way lies in the potential interference by maternal blood contamination since levels of $\alpha_{2}$ macroglobulin are $10^{3}$ fold greater in maternal serum (4). Prior screening of samples for blood contamination excluded such samples from contributing to the reference range. 


\section{References}

1. Brock, D. J. H. (1979) Brit. Med. J. 2, 1402-1403.

2. Smith, C. J., Kelleher, P. C., Belanger, L. \& Dellaire, L. (1979) Brit. Med. J. 1, 920-921.

3. Smith, A. D., Wald, N. J., Cuckle, H. S., Stirrat, G. M., Bobrow, M. \& Lagercrantz, H. (1979) Lancet $I, 685-688$.

4. Brock, D. J. H. (1975) Clin. Genetics 8, 297-301.

5. Wood, P. J., Spencer, K., Noyes, J. \& Coombes, E. J. (1981) J. Clin. Chem. Clin. Biochem. 19, 879-880.

6. Coombes, E. J., Wood, P. J., Spencer, K. \& Batstone, G. F. (1982) Clin. Chim. Acta 122, 249-259.

7. Van Kamp, G. J. \& Calliauw, J. (1980) Clin. Chem. 26, $1362-1363$.

8. Haddow, J. E., Macri, J. N., Munson, M., Baldwin, P. \& Ritchie, R. F. (1977) Second trimester normal amniotic fluid protein levels as determined in the automated immunoprecipitin system. In Technicon International Congress 1976. Technicon, New York, pp. 270-273.
9. Spencer, K. \& Price, C. P. (1979) Clin. Chim. Acta 95, 263-276.

10. Laurell, C. B. (1966) Anal. Biochem. 15, 45-52.

11. Spencer, K., Price, C. P., Anthony, F. \& Wood, P. J. (1979) Clin. Chim. Acta 99, 177-187.

12. Spencer, K. \& Price, C. P. (1980) Clin. Chem. 26, 1531-1536.

13. Price, C. P. \& Spencer, K. (1981) Clin. Chem. 27, 882-887.

14. Büttner, J., Borth, R., Boutwell, J. H., Broughton, P. M. G. \& Bowyer, R. C. (1979) Clin. Chim. Acta. 98, 145F-162F;

J. Clin. Chem. Clin. Biochem. 18, 78-88 (1980).

\section{Dr. K. Spencer}

Department of Biochemistry

Oldchurch Hospital

Romford, Essex

U.K. 
